\title{
Severely Damaged Hip Joints from Avascular Necrosis in a patient with Sickle Cell Trait: Case Report
}

Derrick Tembi Efie ${ }^{* 1}$, Nkeangu Fomengia Joseph ${ }^{1}$, Eugene Vernyuy Yeika ${ }^{2}$ and Siméon Pierre Choukem ${ }^{3}$

${ }^{1}$ Banso Baptist Hospital, Kumbo, Cameroon

${ }^{2}$ Saint Elizabeth Catholic General Hospital and Cardiac Centre Shisong, Kumbo, Cameroon Clinical Research Education Networking and Consultancy, Douala, Cameroon

${ }^{3}$ Health and Human Development Research Network, Douala, Cameroon Department of Internal Medicine and Paediatrics, Faculty of Health Sciences, University of Buea, Buea, Cameroon

*Corresponding author: Derrick Tembi Efie, M.D Banso Baptist Hospital Kumbo, Cameroon, Tel: +237679685659; E-mail: derricko9b@gmail.com

Received date: August 6, 2017; Accepted date: August 19, 2017; Publication date: August 25, 2017

Copyright: (c) 2017 Efie DT, et al. This is an open-access article distributed under the terms of the Creative Commons Attribution License, which permits unrestricted use, distribution, and reproduction in any medium, provided the original author and source are credited.

\begin{abstract}
Background: Avascular necrosis of the femoral head is an increasingly recognized entity especially in the context of sickle cell disease. This entity is however less frequently seen in sickle cell trait; consequently, fewer cases of hip damage secondary to avascular necrosis in persons with sickle cell trait have been reported. This case shows how avascular necrosis can occur, affecting both hip joints in patients with sickle cell trait.
\end{abstract}

Case Presentation: We present the case of a 13-year-old Black African male with sickle cell trait who presented with a 1-year history of progressive bilateral hip pain and deformity. He was diagnosed with bilateral avascular femoral head necrosis and benefited from analgesics and physiotherapy.

Conclusion: Avascular necrosis of the head of the femur is a complication often seen in patients with sickle cell disease but rarely in those with sickle cell trait. This case report shows the infrequent presentation of avascular femoral head necrosis in the context of sickle cell trait and also the limitation of low resource settings in performing hip replacement surgeries and other curative treatment options for this disabling and debilitating condition.

Keywords: Avascular necrosis; Femoral head; Hip replacement; Sickle cell trait

Abbreviations: SCD: Sickle Cell Disease; SCT: Sickle Cell Trait; AVN: Avascular Necrosis ; THA: Total Hip Arthroplasty

\section{Introduction}

Sickle-cell trait (SCT) is the term used to describe the presence, in an estimated 300 million individuals worldwide, of a heterozygous glutamic acid-to-valine substitution in the $\beta$-globin gene on chromosome 11 [1]. Individuals with the SCT have a heterozygous genotype (HbAS) compared to the homozygous genotype (HbSS) carried by individuals with sickle cell disease (SCD).

Bone complications in SCT are rare with a few cases reported over the years starting as far back as the 70's [2,3]. Avascular necrosis $(\mathrm{AVN})$ of a bone is not an uncommon finding among people with SCD, with the femoral head being the most common site of destruction [4] Non-traumatic avascular necrosis of the femoral head is usually of multifactorial aetiology. The lesion affects both hips in 30 - $70 \%$ of cases [5]. The aetiopathogenesis of AVN of the head of the femur is still not fully known. Many risk factors have however been reported to be intimately associated with the occurrence of this pathology. The risk factors include but are not limited to Sickle-cell anaemia, chronic steroid use, alcohol consumption/abuse, smoking, other haemoglobinopathies, coagulopathies, myeloproliferative diseases, leukaemia, chemotherapy, ionizing irradiation, pregnancy, HIV infection and genetic predisposition $[5,6]$. In the case of sickle cell disease (SCD), the main pathophysiologic mechanism of osteonecrosis is the occlusion of microvessels with consequent ischemia and oxygen and nutrient deprivation to the affected bone [7]. The leading cause of osteonecrosis in children is SCD with a $3 \%$ prevalence rate before the age of 15 years [8] Sickle cell trait (SCT) is considered a largely protective condition especially in the context of malaria. Despite this clinical advantage, a series of complications and clinical sequelae, such as exercise-related injury, renal complications, and venous thromboembolism can occur in affected carriers $[1,9]$. To the best of our knowledge, just one case report by Perumal et al. as far back as 1979 reported a possibility of AVN of the femoral head in SCT, but added that more studies are needed [10]. This index case reports and creates awareness to the existence and association of AVN of the femoral head with SCT.

\section{Case Report}

A 13-year-old Black African male presented to the emergency unit of our service with a 1-year history of gradual onset progressive bilateral hip pain, associated with deformity and limping. He had no constitutional symptoms and there was no history of trauma.

He had been diagnosed 2 years ago with sickle cell trait (haemoglobin AS) with a percentage of haemoglobin S of $40 \%$, at another hospital when he presented there with a febrile illness and severe body pains. There was no history of connective tissue disease, chronic alcohol use or chronic use of steroids. On examination, he was well looking with an appropriate weight and height for age. He had pink conjunctivae and anicteric sclerae with normal vital signs. 
Citation: $\quad$ Efie DT, Joseph NF, Yeika EV, Choukem SP (2017) Severely Damaged Hip Joints from Avascular Necrosis in a patient with Sickle Cell Trait: Case Report. J Blood Disord Transfus 8: 387. doi:10.4172/2155-9864.1000387

Page 2 of 3

He had an obvious deformity while walking. There was tenderness and marked limitation in the range of movement of both hips in all planes. His right lower limb was $3 \mathrm{~cm}$ shorter than the left.

A pelvic X-ray done showed severe necrosis of both femoral heads, with involvement of the acetabulum (Figure 1). The right hip joint was, however, more damaged than the left. A complete blood count revealed a haemoglobin of $12 \mathrm{~g} / \mathrm{dl}$ and a haematocrit of $27 \%$, with normal white cell, red cell and platelet counts.

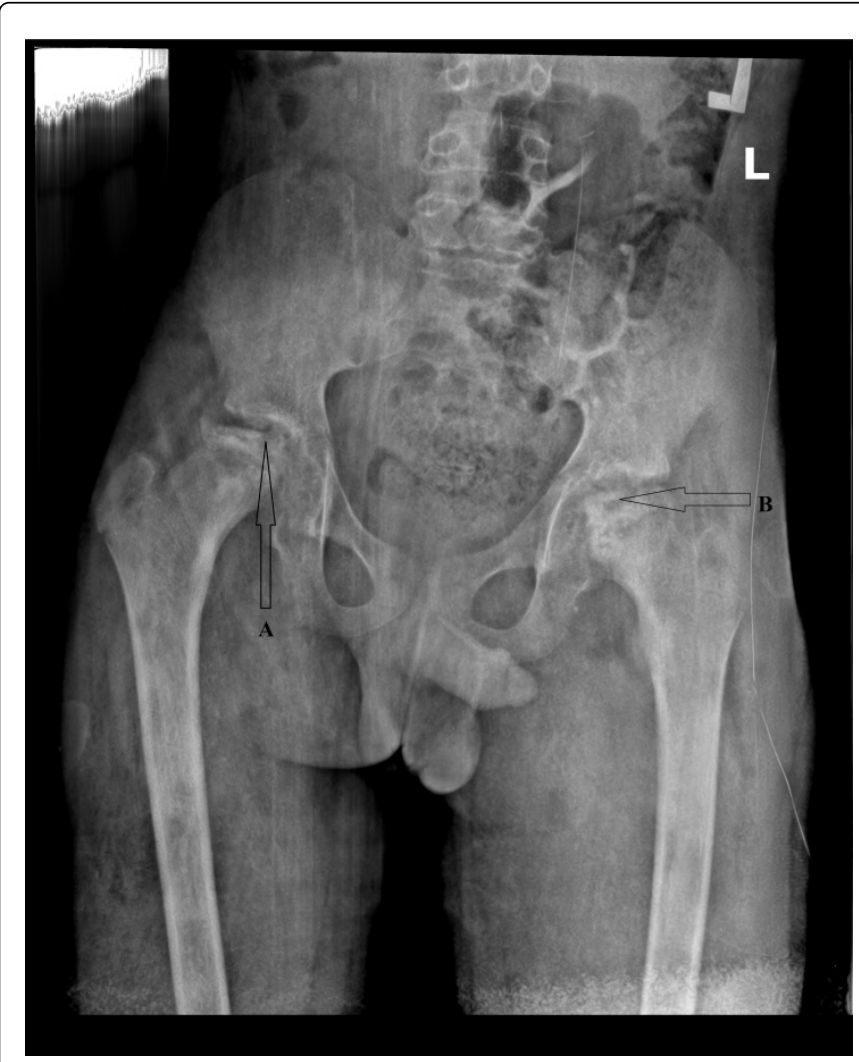

Figure 1. Severe necrosis of both femoral heads, with involvement of the acetabulum.

A diagnosis of avascular necrosis of the femoral heads Ficat and Arlet stage IV was made. The patient subsequently benefited from analgesics and provision of crutches. He is currently on regular physiotherapy.

\section{Discussion}

AVN remain a common complication and an important cause of morbidity in patients with sickle cell anaemia $[4,6,7,11,12]$. Douglas et al. reported a baseline prevalence of osteonecrosis in SCD of 9.0\% [13]. We report this case to highlight the occurrence of AVN of the femoral head in people with sickle cell trait and the associated disability (severely damaged hip joints).

AVN of the femoral head in SCD occurs early with a peak age of incidence between 21 and 30 years [14,15]. Males are more commonly affected [16]. Our patient was a 13-year-old male with a history of SCT.

The commonest presentation of AVN of the hip in symptomatic patients is hip pain [5] as was the case with our patient, in addition to limitation of movement of the hip joint, and limping which he had. Hip involvement is often bilateral $[5,7,17]$, as was the case again with our patient. According to a study by Akinyoola et al., a large proportion of patients with AVN of the femoral head in SCD, however, usually present at a late stage (Ficat and Arlet stage IV) as did our patient, with $18.2-21.2 \%$ presenting with stages II and III and none presenting with stage 1 or 0 [14]. More so, we think that, with a background history of SCT and not SCD, clinicians who came in contact with our patient from time of onset of hip pain to final diagnosis probably did not think of avascular necrosis as the probable cause of his symptoms thus delaying diagnosis.

Treatment options for femoral head osteonecrosis range from nonoperative modalities including restricted weight-bearing, pharmacological agents and biophysical modalities of treatment in early stages of the disease to operative modalities such as core decompression, non-vascularized and vascularized bone-grafting and arthroplasty in later stages $[18,19]$ However, a report by Tripathy et al. depicts that once femoral head collapses $(>2 \mathrm{~mm})$ or if there is secondary degeneration, hip conservation procedures become ineffective and arthroplasty remains the only better option [18]. The patient reported in this case report was diagnosed with Ficat and Arlet stage IV femoral head osteonecrosis with osteoarthritic joint space narrowing and degenerative changes and consequently had to benefit from total hip arthroplasty (THA) according to recommendations. Given the fact, however, that we are in a resource limited setting with unavailable resources for THA, coupled with the financial incapacity of our patient, we opted for a more conservative treatment option which included analgesics with low dose acetylsalicylic acid, provision of a walker and physiotherapy, though these modalities are effective mainly in the early stages of the disease (Ficat and Arlet stage I and II) as reported by Mont et al. [20].

\section{Conclusion}

Though femoral head osteonecrosis is underreported in people with sickle cell trait, it exists and is associated with significant morbidity. This case shows the debilitating complication of avascular necrosis of the femoral head with bilateral severely damaged hip joints in the context of sickle cell trait and the difficulties associated with effective management of this complication in a resource-limited setting.

\section{Declarations}

\section{Ethics approval and consent to participate}

Not applicable

\section{Consent for publication}

A written informed consent to publish was obtained from the patient and her mother.

\section{Availability of data and material}

Not applicable

\section{Competing interests}

Authors declare they have no competing interests. 
Citation: Efie DT, Joseph NF, Yeika EV, Choukem SP (2017) Severely Damaged Hip Joints from Avascular Necrosis in a patient with Sickle Cell Trait: Case Report. J Blood Disord Transfus 8: 387. doi:10.4172/2155-9864.1000387

Page 3 of 3

\section{Funding}

Not applicable

\section{Authors' contributions}

DTE was involved in the management of the patient and wrote the original manuscript. YEV, NFJ and SPC provided critical revision and correction of the manuscript. All authors read and approved the final manuscript.

\section{Acknowledgements}

The authors acknowledge the head of the physiotherapy unit, $\mathrm{Mr}$ Fanfon Timothy and the entire staff of the Physiotherapy Department of Banso Baptist Hospital for assisting in the management of this patient.

\section{References}

1. Key NS, Derebail VK (2010) Sickle-cell trait: novel clinical significance. ASH Education Program Book. 2010: 418-422.

2. Johnson LN (1982) Sickle cell trait: an update. J Natl Med Assoc. 74: 751.

3. Pierce Jr RO (1979) Aseptic necrosis of the hip in sickle cell disease. J Natl Med Assoc 71: 45.

4. Vaishya R, Agarwal AK, Edomwonyi EO, Vijay V (2015) Musculoskeletal manifestations of sickle cell disease: A Review. Cureus 7.

5. Arbab D, König DP (2016) Atraumatic femoral head necrosis in adults: epidemiology, etiology, diagnosis and treatment. Dtsch Arztebl Int 113: 131

6. Akinyoola AL, Adediran IA, Asaleye CM, Bolarinwa AR (2009) Risk factors for osteonecrosis of the femoral head in patients with sickle cell disease Int Orthop 33: 923-926.

7. Silva Junior GB, Daher ED, Rocha FA (2012) Osteoarticular involvement in sickle cell disease. Rev Bras Hematol Hemoter 34: 156-164.
8. Naoum PC, Naoum FA (2004) Doença das células falciformes. São Paulo Sarvier 153-155.

9. Naik RP, Haywood C (2015) Sickle cell trait diagnosis: Clinical and social implications. ASH Education Program Book 2015: 160-167.

10. Perumal JR, Corbett M (1978) Avascular necrosis of the femoral head in sickle cell trait. Rheumatol Rehabil 17: 113.

11. Chinawa JM, Chukwu BF, Ikefuna AN, Emodi IJ (2013) Musculoskeletal complications among children with sickle cell anemia admitted in university of nigeria teaching hospital itukuozalla Enugu: A 58 Month Review. Ann Med Health Sci Res 3: 564-567.

12. Ganguly A, Boswell W, Aniq H (2011)Musculoskeletal manifestations of sickle cell anaemia: A pictorial review. Anemia 2011.

13. Worrall D, Smith-Whitley K, Wells L (2016) Hemoglobin to hematocrit ratio: The strongest predictor of femoral head Osteonecrosis in children with sickle cell disease. J Pediatr Orthoped 36: 139-144.

14. Akinyoola AL, Adediran IA, Asaleye CM (2007) Avascular necrosis of the femoral head in sickle cell disease in Nigeria: A retrospective study. Niger Postgrad Med J 14: 217-220.

15. Milner PF, Kraus AP, Sebes JI, Sleeper LA, Dukes KA et al. (1991) Sickle cell disease as a cause of osteonecrosis of the femoral head. N Engl J Med 325: 1476-1481.

16. Powell C, Chang C, Naguwa SM, Cheema G, Gershwin ME (2010) Steroid induced osteonecrosis: An analysis of steroid dosing risk. Autoimmun Rev 9: 721-743.

17. Min BW, Song KS, Cho CH, Lee SM, Lee KJ (2008) Untreated asymptomatic hips in patients with osteonecrosis of the femoral head. Clin Orthop Relat Res 466: 1087-1092.

18. Tripathy SK, Goyal T, Sen RK (2015) Management of femoral head osteonecrosis: Current concepts. Indian J Orthop 49:28.

19. Sen RK.(2009) Management of avascular necrosis of femoral head at precollapse stage. Indian J Orthop 43: 6 .

20. Mont MA, Carbone JJ, Fairbank AC (1996) Core decompression versus nonoperative management for osteonecrosis of the hip. Clin Orthop Relat Res 324: 169-178. 